\title{
Turkey's EU Quest and Political Cleavages under AKP
}

\author{
Ali Rahigh-Aghsan \\ Department of Society and Globalisation, Roskilde University \\ Universitetsvej1, Roskilde, Denmark \\ Tel: 45-46-742-359Ｅ-mail: aghsan@ruc.dk
}

Received: January 3, $2011 \quad$ Accepted: February 24, $2011 \quad$ doi:10.5539/res.v3n1p43

\begin{abstract}
This article analyses the extent to which the rise of political Islam (Note 1) in Turkey has triggered an intense and polarized debate about the principle eligibility of Turkey to be a full European Union (EU) member state. The Justice and Development Party's (Adalet ve Kalkinma Partisi-AKP) election victories in 2002 and 2007 have been considered to be a serious obstacle to Turkish EU accession. This article argues that even if the AKP government were able to meet the objective criteria of the EU acquis, European opposition to Turkish accession would persist for two main reasons: (1) The overall political targets of political Islam in Turkey seems less compatible with the traditional Turkish EU quest than formerly (2) The Turkish political Islamic turnaround is contributing to a climate of increasing scepticism in Europe, and presents significant obstacles to EU accession. As a result, 'privileged partnership' seems to represent a new pragmatic synthesis of Realpolitik that both Ankara and Brussels should reconsider.
\end{abstract}

Keywords: EU, Turkey, Foreign policy, Security, Europeanization, Political Islam, AKP

\section{Introduction}

Turkey- EU scholars concur that since the AKP government's second term, the impetus behind the domestic reform process specified by the Copenhagen European Council in 1993 and the accession negotiation framework of 2005 has dramatically declined. But they disagree profoundly about why this is the case. The bulk of the current literature on the AKP government's unwillingness and/or inability to persist with the reform packages offers two distinctly different explanations. The first, the so-called 'inside-out approach', focuses on the influence of religion on the AKP's attempt to gain access to the EU (Koprulu 2009, Cizre 2008, Cinar 2008, Casanova 2006, Tibi 2006, and Byrnes and Katzenstein 2006). Here, the core question is the degree to which Turkey's Islamic religious and cultural traditions are compatible with 'European values' (Larrabee and Lesser 2003). It seems that the AKP's loss of enthusiasm to implement the accession reform package is rooted in the party's turn towards a greater emphasis on authority and ecumenism. While there are many different angles on this question, the consensus among these scholars is that "there is an irreconcilable divide between the world view, or cultural orientation, of religious Muslims and that of secular liberals" (Jacoby 2010:113).

The second explanation, the 'outside-in approach', tends to emphasise exogenous or 'structural' factors. These include: (a) strategic calculation (b) state repression and reward (c) economic opportunity spaces, normally accompanied with the public sphere and (d) legal protection to allow the opportunity of governance if they are to be elected. In other words, "in order to establish a democratic system the leaders do not need to be committed democrats" (Yavuz 2009:11). Instead, policy might be understood as a result of existing opportunity structures and self-interest rather than of ideological change. Hence, although the AKP is generally portrayed as an Islamic party, it is usually thought of as very adaptable, and characterised by an endemic rationalism (Özel 2008, Kirisci 2008, Yavuz 2009, Hale 2009, Jacoby 2010, Dogan 2005, and Drorian 2005). For instance, when the AKP came to power in 2002, it took "unexpected steps to compromise with the Kemalist establishment to maintain its domestic and international legitimacy" (Yavuz 2009:10). Scholars who espouse this view consider that the recent political Islamic movement in Turkey "runs on a platform of unabashed and unconditional pursuit of EU membership despite its Islamist pedigree" (Özel 2008:57). The AKP is considered to be a product of the ongoing domestic liberalization of political Islam, and is increasingly dominated by the Anatolian Muslim bourgeoisie and new intellectuals, a partnership intended to create a "magic equilibrium between democracy, secularism, and the place of religion in the public space" (Kirisci 2008:32). Thus, the AKP's loss of enthusiasm for the EU accession reform package is seen primarily as a result of internal tensions/divisions within the party over the 
broadening of its appeal (Yildiz 2008). This tension ebbs and flows with the ongoing wave of democratization of the Turkish state and society, and with structural, economic, cultural and political changes (Yavuz 2009).

The purpose of this paper is to examine the reasons for, and consequences of, the loss of enthusiasm for Europeanization and domestic reforms, notably in the AKP government's second term. First, I attempt to shed light on a relatively little-known aspect of political Islamic activism in Turkey and its correlation to EU affairs. Specifically, I will argue that the AKP government is less pro-European than many scholars assume. Second, I demonstrate that the Erdogan camp is not only ill equipped to meet the accession criteria, but has also put up substantive geographic and geopolitical obstacles, fostered a notion Turkish otherness, and raised questions about the EU's 'absorptive capacity' in relation to Turkey. I conclude by returning to my argument that a 'privileged partnership' may represent a new pragmatic Realpolitik synthesis of that both Ankara and Brussels should reconsider.

\section{How reliable is the Turkish quest for $E U$ entry?}

Political Islam emerged in the nineteenth century mainly to counter Turkey's legacy of pro-Westernization. The primary aims of this movement were to pursue anti-Westernism and anti Europeanism, and it based itself on the promise of a community and state based on Islamic sources. (Note 2) However, the political Islamic movement in Turkey has been neither homogeneous nor static. Since the 1970s, Turkish political Islamic movements may be described in theoretical terms as having followed a trajectory ranging from inherent anti-Europeanism, through pragmatism, and towards a functionally accommodating approach.

The present political Islamist movement in Turkey is divided into two unequal camps, the minority pro-Erbakan camp and the majority pro-Erdogan camp. The pro-Erbakan camp remains the main voice of conservative political Islam in Turkey, due to its strong grassroots organization and a vast social organization based on Milli Görüs (National View) ideological goals (Yesilada and Rubin 2010). This camp has traditionally opposed Turkey's overall pro-Western foreign policy orientations and is ideologically ill-disposed toward Turkey's growing ties with the EU and NATO membership in particular (Jenkins 2008). This camp holds the view that Europeanization will inevitably result in assimilation into European culture and the simultaneous obliteration of Turkish Islamic identity. It therefore endeavours to present Turkey as a pivotal element in the formation of umma and the establishment of closer ties with Muslim countries in the Balkan, Middle East, Central Asia and Caucasus. What makes this camp remarkable is that its members are increasingly involved in an informal network whose aim is to establish an anti-EU coalition with a number of prominent scholars and political actors in Turkey, including "Kemalist-left" organizations under Dogu Perincek's leadership, some ultra-nationalist factions of the National Action Party (Yavuz 2009) and a number of left wing exponents of socialism.

Since the AKP was founded following the closure of the Virtue Party by the Constitutional Court in 2001, the political spectrum has shifted in favour of the pro-Erdogan camp. The majority of leading AKP cadres, who were former member of Milli Görüs, opted to tone down the radical rhetoric of their youth (Sen 2010). The AKP occasionally objects to being described as Islamist and has sought to portray itself as a party of conservative democrats pursuing a pro-EU policy rather than as a religious movement. Yet Turkey's EU membership is considered to be an important goal and the realization of the political and economic accession criteria are understood as an important step toward the modernization of the Turkish state. However, this camp's devotion to Europeanization appears to be arbitrary and functional rather than a real commitment to Europeanization. In fact the pro-Erdogan camp's paradoxical and, to some extent, abiding reservations towards the EU nexus are very complex. If we assume that Europeanization might occur in two distinctly different ways, either through an intergovernmental approach involving formal EU policy decisions and their adaptation by national policies; (Knill 2001) or through a constructivist approach consisting of increased socio-cultural interactions between EU institutions and national actors, (Schimmelfenning et al, 2003) the Erdogan camp appears to be only functionally committed to the Copenhagen and/or accession negotiations criteria. In other words, it understands Europeanization to mean intergovernmental coordination in specific issue areas. In fact, there is no clear indication that the Erdogan camp is committed to Europeanization in the sense of European collective identity, norms and rules, or policy coordination.

The pro-Erdogan camp's functionalist approach to the EU might be conceptualized as a form of "role strain" and/or as a result of contradictory ambitions to promote Turkey's own religious interests, and to engage in a long term Europeanization and democratization process. First, the Erdogan camp has never offered any clarification of the complex relationship between Islam as a religion and as a political tool or agenda. Although, unlike the Erbakan camp, the pro-Erdogan camp has a pragmatic understanding of democracy, it has not yet produced a clear definition of what an "Islamic Democracy" should look like. It is also not entirely clear whether the 
Erdogan camp is committed to secularism as a necessary precondition for bringing Turkey into a democratic, modern, and European present, understood in terms of the protection of minorities, freedom of expression and religion, and an independent judiciary. The Ergenekon scandal is a clear indication hereof (Guida 2010).

Although the Turkish-EU relationship has historically been much more complex than a simple policy disagreement, the Kemalist version of laicism undoubtedly contributes to a climate of scepticism in Europe, although this was mostly because Kemalism was perceived as delaying development, and not because Europe was dissatisfied with the overall direction of development. Today, however, political Islam is becoming an important point of reference in Turkey-EU relations. Yet while in recent decades organized religion has declined in Europe, Turkey is experiencing "a revival of public religion that challenges European universalist norms regarding the (laicist) division between religion and politics upon which Kemalism was modelled" (Hurd 2008:94-95).

A telling example is the higher education reform passed by the AKP dominated parliament in May 2004. The new law allows Islamist high schools (Imam Hatip) students to enter higher education and even professional careers without holding a university degree. According to the chairman of the Education and Science Worker's Union (Egitim-Sen), Zübeyde Kilic, the Council of Higher Education's (YÖK in Turkish) decision to overhaul the university entrance system and make it easier for students who attend vocational and religious high schools to study different subjects at university is entirely ideological and not scientifically or pedagogically motivated.(Note 3) But the most regrettable consequence of this move is the increasing number of students enrolling in religious schools. From 2002-2008, the total number of female students at religious schools increased by almost 245 per cent from 28247 to 68918 . In the same period, the total number of students increased by 182 per cent, from 71100 to 129274 (Cakmak 2009).

Second, Turkish society under the Erdogan government seems, to an alarming extent, to be becoming radicalized, intolerant, and emotionally reactive in its negative perceptions of Western countries. Driven by a lack of conviction that Turkey can ever become an EU member, and by a closer affinity to an anti-Western Islamic political culture, the Erdogan government has incited a climate of radical anti-Western and anti-EU sentiments both within the state and society at large, in close collaboration with some segments of the military, media, and rising business interests and elite groups. This tendency is borne out by a number of research polls which have been conducted in Turkey in recent years. For instance, according to the 2009 nationwide survey 'Radicalism and Extremism' in Turkey, 86 per cent of Turkish people believe that the United States is seeking to divide and weaken Turkey. In response to a question about how values priorities, only 13 per cent claim that democracy is the most important value, compared to religion at 62 per cent and secularism at 16 per cent. In addition, the recent 2010 Transatlantic Public Opinion Survey reveals that the percentage of Turks who consider that Turkey should cooperate closely with Middle Eastern countries in international matters has doubled to 20 per cent since 2009. This increase was accompanied by a nine-point decline in those who said Turkey should cooperate with EU countries - from 22 per cent in 2009 to 13 per cent in 2010 - and at the same time those who said Turkey should act alone on international matters increased by 34 per cent. (Note 4) In a similar vein, Esmer's 2009 research concluded that 76 per cent of Turks are of the opinion that the EU intends to divide Turkey, and 81 per cent believe the EU's mission is to spread Christianity at the expense of the Muslim World (Koprulu 2009).

Third, the new Turkish foreign policy doctrine which calls for active engagement within the regional political systems in the greater Middle East appears to have had a profound impact on the formal Europeanization process of Turkish foreign policy behaviour (Murinson 2006).This doctrine is part of an explicit attempt to develop a multi-dimensional foreign policy along the lines popularized by the strategic depth doctrine. As President Gül put it, "What Turkey is doing is clear. Turkey, surely, is moving simultaneously in every direction, towards East and West, North and South" (Cengiz 2009:10). In this context, the AKP considers Turkey not as a "bridge" between the West and the Muslim world but rather as a "central country" that is transforming itself from a "static and single-parameter policy" state into a "problem solver" with a key role to play in assuring global and regional peace and stability (Davutoglu 2009). Here, the strategic depth doctrine has to large extent facilitated both a broadening and a 'softening' of Turkish foreign policy (Cengiz 2009). This about-turn triggered a well-founded suspicion among many observers that Turkey is pursuing an assertive foreign policy and forming its own axis based on political Islamic - or neo-Ottoman if preferred - ideological premises. (Note 5)

Some scholars consider this new orientation to be an advantage that could facilitate convergence between the EU and the Middle East (Yavuz 2009, Hale 2009 and 2006, Kirisci 2008, and Özel 2008). In the European Union, however, the AKP government's new foreign policy appears to have provoked a generally ambivalent reaction. On the one hand, the Turkish 'zero problems' doctrine has been hard to oppose, in principle. It is "obviously better to try to resolve problems than to continue with xenophobic attitudes which had assumed that Turkey was 
"surrounded by enemies" (Hale, 2009:156). On the other hand, pro-activism since 2007 has led to deteriorating relations with Israel after Davos and the Gaza-bound ship Mavi Marmara raid incident, active engagement in Hamas and Besir's regime in Sudan, and Turkey's recent strong links to Hezbollah in south Lebanon, have put Turkey on a collision course with both US and EU interests. Particularly critical was Turkey's recent 'no' vote when the UN Security Council passed the fourth round of sanctions on Iran because it demonstrated a lack of unity within the international community and simultaneously put the P5+1 countries in an unfavourable situation to implement effective balancing and containment policies towards Iran. Another milestone in the deterioration of Turkey's relations with the West was the Turkish government's reluctance to participate in the NATO-led missile shield project designed to counters possible missile strikes from Iran and Syria. Turkey's precondition for approving NATO's Missile Defense Shield Initiative was to remove Iran's name from the agreement, even though Iran has been explicitly identified as the main threat against the Alliance. However, instead of damaging Turkey's standing with the EU, this action earned the AKP government strong praise from fervently anti-American Muslim leaders such as Ahmedinejad, giving Turkey a credibility which it had previously lacked in the rest of the Muslim world.

Thus, Turkey's EU quest does not appear to be very compatible with the overall ideological targets of the pro-Erdogan camp. Even though the AKP emerged from the election of 2007 with an even larger support coalition which could have been utilized to re-activate a large-scale reform agenda, the party increasingly focused on promoting fundamental 'Islamic freedoms' such as Islamic schools and allowing female students to wear the headscarf at universities. Its loss of enthusiasm to implement the key reforms required for EU accession "helped to create a very serious backlash and even alienated liberal opinion which had hitherto been quite supportive of the AKP's reformist and moderate credentials" (Önis 2008:4).

Consequently, Turkey's current negotiations on the objective criteria for accession have been stalled, or at best have led to "a regrettable slowdown in the reform process". (Note 6) The negotiators have opened only eleven of the required 35 chapters, only one of which (Science and Research) has provisionally been closed. Given that eight negotiation chapters have been frozen because of a dispute over the divided island of Cyprus, other chapters have been blocked by France and Austria, and still others cannot be addressed because the Turkish government has not completed the necessary preparations, negotiators are all but running out of subjects to discuss, which is putting a de-facto stop to the opening of new negotiation chapters.

\section{Why the rise of political Islam contributes to additional substantive criteria that are blocking Turkey's EU entry}

The rise of political Islam, in turn, feeds sceptics in European countries who point to its impact on substantive criteria, including geographic and demographic belongingness, Turkish otherness, European public opinion and the political will of EU countries regarding absorption capacity. This section addresses each of these points in turn.

\subsection{Geographical and geopolitical arguments}

The geographical and demographic argument against Turkey's accession to the EU is arguably relevant even after Ankara and Brussels commenced accession negotiations in October 2005. Ever since the formation of the Turkish republic, it has been the generally accepted wisdom that Turkey lies at the geographical periphery of a number of regional systems: the Northern Tier, (Note 7) the Middle East, Europe, the Balkans, the eastern Mediterranean, Central Asia, and the Caucasus. From a systemic perspective, during the Cold War Turkey had an insulating position among these regional security systems/complexes, since it occupied the boundaries of indifference between the self-contained dynamics on either side of them.

However, in the post bipolar world it seems that this insulating position is in transition. Turkey's strategic depth doctrine, combined with its strategic geography and changing security environment, point to its intent to play a pro-active role in the Middle East/Northern Tier region, rather than that of a peripheral actor in the security regions surrounding it. On a global level, the disappearance of the Soviet threat removed the main rationale behind the traditional Turkish pro-Western security orientation, simply because of Turkey's waning dependency on the West for security guarantees. At the regional level, the focus of threats and challenges to Turkish security has shifted. Today, the nature of Turkey's foreign relations is to a significant extent determined by what transpires to the south and east of its borders rather than to the west.

Given the complexity and significance of the security environment at its southern and eastern borders, Turkey has increasingly embraced a new strategic orientation involving direct contacts to the new government in Iraq, even engaging in direct dialogue, since late 2008, with the Kurdistan Regional Government in northern Iraq, and with President Barzani in particular. This has produced an urgent situation leading to a spill-over affect on the 
Kurdish problem at home, a blossoming relationship with Syria, and direct involvement in a complicated situation in Iran (including its nuclear program) in response to outside challenges (Hale 2009).

Often the justification put forth at these junctures is the sensitivity of Turkey's regional belonging, and specifically a recognition that Turkey's domestic stability and prosperity depend on regional stability, which in turn requires minimizing tensions with Turkey's Muslim neighbours. Yet contrary to the assertions of some scholars, (Note 8) Turkey's recent diplomatic activism aimed at broadening and deepening ties with its Muslim neighbours does not exclusively represent an attempt by Ankara to reduce regional tensions and insure stability. In fact, during the Cold War, the guiding principle of Turkey's relations with its immediate neighbours was mutual respect and neutrality (i.e. 'peace at home, peace abroad' promulgated by the founder of modern Turkey, Kemal Ataturk). Indeed, since its participation in the Korean War, Turkey has never been involved in regional or global conflict. Rather, Turkey's recent foreign policy reflects a recognition that the change in its geostrategic environment in the post bipolarity era, combined with the AKP's focus on the transnational political force of Islam, ethno-cultural and racial ties, should be significant factors in defining Turkish geographical/regional belongingness. The apparent deterioration of Turkey's relations with Israel is a clear indication hereof.

It would seem likely that the religious, cultural and racial characteristics shared by Turkey and its Muslim neighbours would cause them to pay more attention to each other in general, and in particular might legitimize mutual interventions in each other's security affairs. In defining the shape and structure of Turkey's geographical belongingness, the idea of Islam as a transnational political force, combined with cultural and racial patterns, may well be important contributing factors in the creation of a potent regional political arena.

From a historical perspective, the strategic interests shared by Turkey and the Northern Tier have been striking. Turkey has been a core member of the Baghdad pact, the Central Treaty Organization the CENTO-alliance, the Regional Cooperation for Development (RCD) based on the Izmir treaty, and the Economic Cooperation Organization (ECO). These regional initiatives were basically motivated by joint security interests in the Northern Tier countries and Turkey, as well as the presence of a one-dimensional threat from the former Soviet Union, which made such regional institutionalization systems advantageous.

Indeed, in geographical terms, only a small part of Turkey's territory is in south-eastern Europe. Over 95 per cent of its territory is located in Anatolia, in what has for centuries been called the Northern Tier. Neither is Turkey geographically situated in the Middle East. Even though the Northern Tier region, including Turkey, Iran and Afghanistan share an enormous landmass (2.5 million square $\mathrm{km}$ ) with the Middle East in the Persian Gulf, the Mediterranean Sea and the Red Sea, the Anatolian plateau in Northern Turkey and the Iranian plateaus are clearly separate from the rest of the Middle East. Turkey as a core member of the Northern Tier region is physically set apart from the rest of the Middle East by the Taurus-Zagros mountain system that separates the plateaus from the valleys and plains of the Fertile Crescent (Ramazani 1966).The Taurus-Zagros mountain system is divided between the Arab world in the Middle East and the non-Arab world (Persian-Turks) in the Northern Tier. This is a conclusive factor for the Northern tier both as a community of people and as a geographical region.

Turkey's location in the Northern Tier is not only a matter of geography, but also involves cultural, ethnic, linguistic homogeneity, and religious affinities. The major groups of people of the Northern Tier are the Turks and the Persians. Indeed, it is no exaggeration either to claim that the Northern Tier has a dual Turkish-Persian heritage in terms of cultural and ethnic affinity, languages and even religious beliefs. In fact, all the nationalities of the Northern Tier, apart from the Pakistanis, can claim cultural affinity with either Turkey or Iran, and in many cases both. The Turkmen, Uzbeks, Kazakhs, Kyrgyz and Azeri speak a kind of Turkish language and share many cultural attributes with Turkish people, while the Tajiks, Afghans and Uzbeks have similar connections to Iran. It is no coincidence that when asked to name the country or region which they most associate with 'warm feelings', more Turks answered Iran than the EU. (Note 9) Thus, despite the fact that a large number of contemporary Turks can trace their ethnic origins to the European parts of the Ottoman Empire (mainly the Balkan region) which came to Anatolia as a result of the population exchange program after World War I (McMarthy 2001), it is apparent that Turkey might naturally be considered an integral part of the Northern Tier region in demographic terms.

However, the final judgment about Turkey's geographical belonging within Europe will depend on political decisions and/or a common consensus among European states. And since the rise of political Islam in Turkey, the EU member countries are increasingly divided on this issue. Proponents of Turkey's affiliation with Europe stress the geopolitical advantages, and view Turkey as an extremely important asset for European security. They argue that during the Cold War, Turkey successfully controlled Soviet naval access to the Black Sea and the 
strategically important Straits in the Mediterranean; and that since the end of the Cold War; Turkey's security role has gradually changed from being a bulwark against the Soviet threat to being a buffer state. In Grossman's words, Turkey has transformed itself from a wing state to a front state (Note 10) in international hot spots of Islamic radicalism in Iraq, Iran, Afghanistan and Syria. It is assumed that the strategic importance of Turkey has increased in the post September 11 era. The inclusion of Turkey as a predominantly Muslim country in the community of developed secular-democratic states is argued by some to have strengthened the soft power of the EU and the United States in its efforts against international terrorism (Oguzlu 2004). The EU would find it very difficult to undertake military operations or even peacekeeping, humanitarian relief and crisis management in the Middle East, the Balkans, Central Asia, and the Caucasus without Turkey's involvement (Drorian 2005). For the same reason, those who favour Turkey's accession consider that the debate about Europe should be more concerned with the latter's role as a strong global power in the twenty-first century than about its borders. Turkey's approach towards the CESDP is not only considered to be a necessary step in promoting Europe as an independent "third power", (Note 11) but as the second largest standing army in NATO, Turkey can also potentially contribute to the military aspect of the CESDP and promote a unified security and defence strategy in Europe.

Moreover, Turkey is seen as an important security provider to the EU in terms of energy. Although Turkey lacks its own energy reserves, it plays a key geopolitical role in energy transit as it lies between the Middle East, Russia and the Caucasus, and the large energy markets of Europe, the West and even the US. This is evident, for instance, in the Baku-Tbilisi-Ceyhan pipeline which has carried oil from the Caspian to the Mediterranean since 2006, and in many other projects, including the Nabucco pipeline which supplies Caspian gas to the EU, bypassing Russia (which is still under consideration). As Aydin and Acikmese emphasize "[the] EU imports approximately 60 per cent of its energy needs from Turkey's neighbouring regions and attaches utmost importance to secure access to these resources. Thus Turkey's location at the crossroads of major new energy transport projects, long-established Iraqi pipelines to Iskenderun, as well as the Turkish Straits linking the Black Sea and Mediterranean elevates Turkey to a vital position in the Union's energy Strategies" (Aydin and Acikmese 2004:54). Major natural gas reserves are located in only a few regions where production and transport costs are economically viable for the EU, e.g. Russia, the Caspian region including Central Asia and the Caucasus, the Near East and Nigeria. Since ten gas producers, who account for 35.5 per cent of global gas reserves, are or might potentially be interested in using Turkey as a transit country to the EU, this might add to Turkey's importance in terms of energy security (Tekin and Walterova 2007). Turkey's significant role in assuring secure energy supplies to the EU is also likely to increase as the EU's energy demands grow. According to the EU Commission's Green Paper, EU energy imports of fossil fuels (oil, natural gas and coal) will rise by 70 per cent by 2030, and imports of natural gas will rise by 80 per cent over the coming 25 years. (Note 12) Hence, Turkey's participation in the EU's foreign and security policy, with full and equal participation in decision-making processes in EU-led operations and in NATO, is considered an important element for the EU's new ESDP (Arkian 2006).

Opponents of this view emphasize that unlike the Central and Eastern European countries, Turkey has lost its strategic and geopolitical position as a NATO member who defends Europe's southern flank, adding that the AKP government's turnaround in favour of the Middle East security formation further undermines Turkey's security and foreign policy relations with EU. Turkey is considered a security burden which poses challenges to the EU in terms of WMD, the illegal trafficking of drugs, people and terrorism. Turkey's southern and south-eastern borders with the international hot spots of Iraq, Iran, and Syria pose geopolitical and security disadvantages in terms of closer linkages between Turkey and the EU. Here, the current government no longer appears to be an unconditionally strong and pivotal ally of democratic nations.

In recent years, there appears to be a growing consensus among European countries to keep Turkey out of the EU as a full member state, but to let Turkey continue to play its NATO role as a 'buffer state' to secure Europe against dictators, terrorists, and Islamic radicals in the conflict-prone regional subsystems in the Middle East, the Balkan, and the Caucasus and Central Asia. Likewise, Turkey is generally portrayed as a serious security problem in terms of its domestic politics in the Kurdish region (Kurdistan Workers' Party, PKK), its human rights record, and its foreign policy (disputes with Israel, Armenia, Greece and Cyprus). Turkish incorporation into the CESDP would not only bring those internal security issues into the EU, but would also undermine the EU's longstanding objective to establish a coherent foreign and security policy.

\subsection{Turkish otherness and accession}

While the pro-Erdogan perspective strongly emphasizes Islamic identity and Ottoman nostalgia, branding the Christian West as the 'other', the majority of Europeans have similarly defined Turkey as Europe's 'other' 
(Jenkins 2008). There is clearly a group of Europeans who are concerned about Turkey's admittance to the EU mainly because of Turkey's predominantly Muslim population. However, while in Europe the religious argument against Turkey's accession to the EU has been implicit rather than explicit, in Turkey there is an explicit, commonly shared wisdom that the main reason for European objections to Turkish EU entry are its cultural and religious otherness. Even this view is fundamentally flawed, as it vastly exaggerates the idea of a European Christian club. But although cultural and religious factors are significant in Europe, and being European is a cultural claim rather than a political right, Europe's hesitant attitude towards Turkish membership is not only about defending the idea of a Christian club. In fact, opposition to Turkish accession comes from religious as well as nonreligious and secular Europeans alike. The consensus among these groups, however, is that there is an anxiety and fear of the spectre of an Islamification of Europe (i.e. an anti-Islamic sentiment) and/or an inherent tension between Islam and the values of the European project (Delanty 2008 and Sivanandan 2006).

Indeed, the tendency to distinguish Turkey from the rest of Europe in terms of culture and religion is neither a product of the internal political and social problems of the EU countries (the Islamic diasporas in Europe) such as xenophobia, nor does it stem from sui generis factors, though each of these factors may weigh in to some extent. Opposition to Turkish accession based on Turkish otherness is rooted in a more controversial issue regarding the intimate relationship between Islam and politics in contemporary Turkey, which is considered to be detrimental to Western secularism. The contemporary rise of political Islam seems to escape the explanatory confines of the European conception of secularism. As Hurd emphasized, "[The] Turkish case is therefore controversial in cultural and religious terms not only because it involves the potential accession of a Muslim-majority country to an arguably, at least historically, Christian Europe, though this is important, but also and more fundamentally because it brings up long dormant dilemmas internal to Europe regarding how religion and politics relate to each other" (Hurd 2006:402). This "otherness" sticking point is what many scholars refer to as hidden European fears and prejudices over Turkish EU entry.

The driving force behind the otherness argument against Turkey's accession stems from at least two main fears. First, in European politics Islam appears undemocratic and stands in sharp contrast to Western civilization. Political Islam is therefore seen as a backlash against the foundational principles of the secular collective order. As Hurd argues, "Distinctions between religious and political authority are not only historically absent from Muslim-majority societies but are unthinkable due to fixed characteristics of the Islamic religion" (Hurd 2008:118). Second, the recent alleged political Islamic turn represents an alternative trajectory that diverges fundamentally both from European secularism and the French-inspired Kemalist laic version. Like secular Turks, a large number of Europeans are concerned with what they perceive as the progressive "Islamization" of Turkish society in recent years. This new wave of Islamization is pushing Turkish society further away from Europe, contributing to an increasingly strained climate between Turkey and the EU. As Roy argues, "Turkey will be rejected from the European Union not because the Turkish state fails to satisfy the EU's demands to democratize, which would be a good reason, but because Turkish society is not [European], meaning that it does not share the fund of Christianity that serves as the foundation of laicism itself" (Hurd 2008:91). However, Turkey's accession to the EU appears to be the symbolic carrier of domestic European angst toward political Islam (Hurd 2006). Sivanandan (2006) has referred to this as the 'new spirit of xenophobia and xeno-racism' in Europe and the Western world. This is reminiscent of the fact that the image of a Christian Europe seems still influential and increasingly relevant in the political struggle over the future of the EU-Turkey relations.

\subsection{From absorption capacity to integration capacity}

The concepts of the absorptive and/or integration capacity of the EU are applied in the following to suggest that there are both objective and substantive limits to Turkey's integration in the EU. The objective aspects of the EU's absorption capacity will be monitored by the EU Commission during the negotiations: these encompass the whole range of issues set out in the Negotiating Framework, which will be used to inform an assessment by the Council as to whether this membership condition has been met. The objective components comprise three overarching dimensions: (1) institutional conditions for absorbing new member states, (2) financial conditions, the EU's internal market, labour market, budget, and Eurozone and (3) conditions relating to foreign and security policy. The objective criteria are officially defined as the "capacity to act and decide according to a fair balance within institutions; respect budgetary limits and implement common policies that function well and achieve their objectives". (Note 13)

The substantive components of absorptive capacity consist of political attitudes in the EU countries and public opinion regarding Turkey's entry. The questions of political will and/or public opinion seem to be decisive factors in Turkish EU membership. This is mainly because these substantive criteria explicitly signal that the 
EU's enlargement towards Turkey is still an open-ended question for the Commission and the so-called 'old European' states, rather than merely a matter of adjusting the Union's integration capacity and pace. Thus, Turkey's EU quest seems to a large extent bound up with its image and public perception in Europe.

Traditionally, Turkey's image has been less than positive, and public opinion generally opposes Turkish membership, though with varying degrees of intensity. However, under Erdogan's government, support for Turkish accession among European citizens has dropped substantially. According to the recent Transatlantic public opinion survey, in 2010 only 23 per cent of the EU public still believed that it would be a good thing to include Turkey in EU. The same survey noted 30 per cent of support in 2004. Traditionally, opposition to Turkey among EU countries was also related to country-specific broader views of the future of the Union. Belgium, France, Germany and Italy feared that including Turkey would spell the end of the federalists' notion of a political union. Conversely, in the United Kingdom (UK) and the Scandinavian countries that have been less keen on federalism, enlargement toward Turkey is viewed more positively. However, this has not been enough to prevent a drop in support for Turkish accession even among the most pro-Turkey countries in Europe. Still, opposition to Turkish accession remains strong even after Turkey implemented reforms that were considered desirable among some EU member states. According to the Financial Times/Harris poll, support for Turkish membership in the UK after the reforms decreased from 23 per cent to 21 per cent in 2007. (Note 14) However, the most remarkable fact is that even the addition of further reform criteria that Turkey should meet has not overwhelmingly changed some EU citizens' perceptions about Turkey's accession. This indicates that the core members of the EU (Germany, France, and Italy) are determined to attach decisive weight to substantive criteria in the matter of Turkish EU accession.

\section{Conclusion: Privileged partnership as a new pragmatic synthesis of Realpolitik}

The rise of the Erdogan camp as an incoherent political-religious movement appears to have had a mixed outcome for Turkey. Remarkable constitutional changes have occurred, only to fall short of expectations. The military has only partially been placed under civilian control, and minority rights have been improved but then subject to new religious restrictions. Thoroughgoing national reform packages were implemented to meet the EU criteria outlined by the Copenhagen European Council and the Accession Negotiation Framework, but were then virtually undone, leaving the AKP ill equipped to deal with the Europeanization process. In particular, the loss of enthusiasm for Europeanization and domestic reforms in the AKP government's second term represents quite a paradox. This is evident in the absence of initial steps towards a democratic solution to the Kurdish problem, or towards an internationally acceptable solution to the Cyprus dispute along the lines of the Annan Plan. The victory of the AKP as the main exponent of political Islam activism in Turkey is less pro-European and more reluctant to continue its Europeanization process than many scholars suggest. Thus, not only is political Islam in Turkey an obstacle to EU rapprochement, it has also further jeopardized its prospects of EU accession.

It remains uncertain to what extent Turkey is ready to align itself with EU positions. The Erdogan camp's ability to shape and determine Turkey's EU accession will be weakened by the AKP government's growing Islamic populist and confrontational politics, as we have witnessed recently. The growing political instability will further make it difficult for Turkey to pursue a coherent and proactive EU policy. Thus, Turkey under Erdogan seems neither in a position to complete its EU membership bid, nor to steer a proper democratic reform process.

More precisely, despite the remarkable progress Turkey has made against seemingly overwhelming odds, the rise of political Islam is contributing to a climate of mistrust in relation to Turkish geographical belongingness, its cultural and demographic otherness and the public's perceptions, which has implications that go beyond the largely technical and bureaucratic criteria of the accession negotiation frameworks. Even though these substantive sticking points are vague sentiments and are not rigorously defined, they nevertheless stand for political reality in the debate over Turkish accession. This argument leads to three conclusions. First, the emergence of political Islam itself is a destabilizing factor in secular Europe. Europeans are warier of the pro-Erdogan camp than has previously been assumed. Recent Turkish forms of secularism are ill-founded and need to be parochialized. The pro-Erdogan camp's particular interpretation of secularism, rooted in the Sunni-Hanefi version of political Islam, signals a fusion between religious and secular reasoning that is seen as additionally antithetical to what Europeanization stands for (irrespective of whether the latter is based on specific trajectory of secularism or on a civic culture i.e. a sense of Europeanness). This development seems to have unified European disagreement over Turkish accession between those who see Europe as a Christian club (Germany, France, Austria and Holland) and those open to a more religiously pluralistic European identity (the UK, Italy, Portugal and Spain). Second, the pro-Erdogan camp has not issued a single definition of Europeanization in terms of political and cultural rapprochement. Belonging to Europe is, after all, also an 
identity claim. It is articulated with shared values, history, culture and memory that work as a basis for economic, political and security agreements and alliances (Wallace 2002). Third, it seems that the pro-Erdogan camp is less equipped to meet the EU's 'absorption capacity' criteria in general and societal absorption- read religious absorption- in particular that are needed for successful conclusion of the accession negotiations. The recent absorption capacity debates illustrate the EU countries' inclination to make a politically-determined decision on Turkish entry.

Thus, the Erdogan camp's ambivalent attitude towards the EU, combined with important substantive obstacles, the political positions of 'old European' states - France and Germany - and the European public's perception about Turkey's EU accession raise the question of whether a privileged partnership might in fact be a more feasible option both for Ankara and Brussels. Such a partnership could lead to Turkish access to the free movement of goods, services, and capital, market liberalization and the further opening of agriculture trade. At the same time, security and foreign policy issues could be addressed through bilateral cooperation, which would seem to be desirable both for Turkey and the EU. And EU-Turkish energy policy could be linked to the EU's Eastern neighbourhood policy initiative with Armenia, Azerbaijan, Belarus, Georgia, Moldova and Ukraine. Seen in this context, it appears that privileged partnership seems to represent a viable alternative to Turkey's integration with the EU which, besides mundane Realpolitik, is conditioned by the inherent political, religious, ideological, cultural and geographic complexity of Turkey. This is not to say that a privileged partnership should be the alternative final destination for Turkey's integration with the EU, or that the rise of the new Islamists is the final stage of Turkish political development. A new wave of change in Turkish politics could change the whole picture regarding both objective and substantive criteria. The idea of a secular, pro-Western Turkish EU quest can neither be definitively laid to rest, nor indefinitely postponed.

\section{References}

Arkian, H. (2006). Turkey and the EU - An awkward candidate for EU membership? Ashgate Publishing.

Aydin M. \& Acikmese, S.A. (2004). To be or not to be with Turkey: December 2004 Blues for the EU. Turkish Policy Quarterly, 3/3.

Cakmak, D. (2009). Pro-Islamic Public Education in Turkey: The Imam - Hatip Schools. Middle Eastern Studies, 45/5, 825-846.

Casanova, José. (2006). The Long, Difficult, and Tortuous Journey of Turkey into Europe and the Dilemmas of European Civilization. Constellations, 13/ 2, 234-247.

Cengiz, Candar. (2009). Turkey's “Soft Power" Strategy: A New Vision for a Multi-Polar World, SETA Policy Brief, No: 38 .

Cizre, Ümit. (2008). Secular and Islamic Politics in Turkey - The making of the Justice and Development Party. Routledge Publishing.

Davutoglu, A. (2008). Turkey's Foreign Policy Vision: An Assessment of 2007. Insight Turkey, 10/1, 77-96.

Delanty, Gerard. (2008). Fear of Others: Social Exclusion and the European Crisis of Solidarity. Social Policy, 42/6, 676-690.

Dogan, Erhan. (2005). The Historical and Discursive Roots of the Justice and Development Party's EU Stance. Turkish Studies, 6/ 3, 421-437.

Drorian, Sevgi. (2005). Rethinking European Security: The Inter-regional Dimension and the Turkish Nexus. European Security, 14/ 4, 421-441.

Guida, M. (2010). The New Islamists' Understanding of Democracy in Turkey: The Examples of Ali Bulac and Hayreddin Karaman. Turkish Studies, 11/ 3, 347-370.

Hale, W. (2009). Turkey and the Middle East in the 'New Era'. Insight Turkey, 11/3, 143-159.

Hurd, E. S. (2006). Negotiating Europe: the politics of religion and the prospects for Turkish accession. Review of International Studies, 32, 401-418.

Hurd, E. S. (2008). The Politics of Secularism in International Relations. Princeton University Press.

Jacoby, T. (2010). Identity Politics, Turkey and the European Union. Mediterranean Politics, 15/1, 109-119.

Jenkins, Gareth. (2008). Political Islam in Turkey - Running West, Heading East? Palgrave MacMillan. 
Kirisci, Kemal. (2008). Religion as an Argument in the Debate on Turkish EU Membership. In Dietrich Jung and Catharina Raudvere (Eds.) Religion, Politics, and Turkey's EU Accession. Palgrave MacMillan.

Knill, C. (2001). The Europeanization of National Administrations: Patterns of Institutional Change and Persistence. Cambridge University Press.

Koprulu, K. (2009). Paradigm Shift in Turkey's Foreign Policy. The Brown Journal of World Affairs, XVI/I, 185-201.

Larrabee, F.S. \& Lesser, I. (2003). Turkish Foreign Policy in an Age of Uncertainty. Santa Monica, CA: RAND. McMarthy, J. (2001). The Ottoman Peoples and the End of Empire. Oxford University Press.

Murinson, A. (2006). The Strategic Depth Doctrine of Turkish Foreign Policy. Middle Eastern Studies, 42/6, 945-964.

Oguzlu, H.T. (2004). Middle East Policy, 11/1, 98-105.

Önis, Z. (2008). Recent Foreign Policy Attitudes in Turkey - How to Reverse the Gradual Shift Away From Europeanization? Danish Institute of International Studies.

Özel, Soli. (2008). A Passionate Story with Europe. European Security, 17/1, 47-60.

Ramazani, R. (1966). The Northern Tier: Afghanistan, Iran, and Turkey. D.Van Nostrand Company.

Schimmelfennig, F., Engert, S. \& Knobel, H. (2003). Costs, Commitment and Compliance: Latvia, Slovakia, Turkey. Journal of Common Market Studies, 41/3, 495-518.

Sen, Mustafa. (2010). Transformation of Turkish Islamism and the Rise of the Justice and Development Party. Turkish Studies, 11/1, 59-84.

Sivanandan, A. (2006). Race, Terror and Civil Society. Race and Class, 47/3, 1-8.

Tekin, A. \& Walterova, I. (2007). Turkey's Geopolitical Role: The Energy Angle. Middle East Policy, XIV/1, 84- 94.

Tibi, Bassam. (2006). Europeanizing Islam or the Islamization of Europe: Political democracy vs. cultural difference. In T.A. Byrnes and P.J. Katzenstein (Eds.), Religion in an Expanding Europe, (pp.225-255). Cambridge University Press.

Wallace, W. (2002). Where does Europe end? Dilemmas on inclusion and exclusion. In Zielonka J. (ed.), Europe unbound. Enlarging and reshaping the boundaries of the European Union. Aldershot: Ashgate.

Yavuz, M. H. (2009). Secularism and Muslim and Democracy in Turkey. Cambridge University Press.

Yesilada B. A. \& Rubin B. (2010). Introduction. Turkish Studies, 11/1, 3-7.

Yildiz, Ahmet. (2008). Problematizing the intellectual and political vestiges: From 'welfare' to 'justice and development'. In Ümit Cizre (2008).

\section{Notes}

Note 1. In this article the concept of Political Islam refers to a set of worldviews and practices which contend that Islam has a theory of politics and state-building.

Note 2. Erbakan, Necmettin (1975). Milli Gorus, Istanbul Dergah Yayinlari. See also Erbakan Necmettin 1991, Turkiye'nin Temel Meseleleri, Ankara: Rehber Yayinlari.

Note 3. Hurriyet, (July 22, 2009), [Online] Available: http://www.hurriyetdailynews.com/h.php?news=yok-decision-to-cripple-education-system-says-experts-2009-07 $-22$.

Note 4. Transatlantic Trends, Key Findings (2010). A project of the German Marshall Fund of the United States, chart 13. [Online] Aavailable: www.transatlantictrends.org.

Note 5. See Michael Rubin (2004). "Shifting Sides? The Problem of neo-Ottomanism". Middle East Forum.

Note 6. A report published 7 September 2009 by a panel of European grandees, The Interdependent Commission on Turkey.

Note 7. Until 1990, The Northern Tier as a region include only four countries; Afghanistan, Iran, Turkey and Pakistan. The concept was primarily a politico-military concept, aiming at a 'collective security system' which 
manifested in the CENTO on the southern periphery of the Soviet Union. The collapse of the Soviet Union resulted in the enlargement of the Northern Tier to Central Asia and the Caucasus.

Note 8. For instance Yavuz 2009, Önis 2008, Cengiz 2009, Candar 2009, and Hale 2009.

Note 9. Turkey in the EU - What the public thinks, published in EurActiv 29 May 2008.

Note 10. Quoted in Arkian, H. (2006). Turkey and the EU - An awkward candidate for EU membership? Ashgate Publishing (P.203).

Note 11. See Bonnén, P. (2003). Towards A Common European Security and Defence Policy - The Ways and Means of Making It a Reality. Transaction Publishers.

Note 12. European Commission. (2006). Green Paper: A European Strategy for Sustainable, Competitive and Secure Energy.

Note 13. European Commission, Enlargement Strategy Paper, COM 561 final, (Brussels 9 November 2005).

Note 14. Available from: http://www.harrisinteractive.com/news/allnewsbydate.asp?NewsID=1228. 